\title{
WPKYW PRAWA EUROPEJSKIEGO NA UNORMOWANIA PRZESTĘPSTWA O CHARAKTERZE TERRORYSTYCZNYM W POLSCE
}

\section{Uwagi ogólne}

Terroryzm jest zjawiskiem bardzo złożonym i różnorodnym. Dlatego też jego ujęcie w normy prawa karnego napotyka na poważne trudności. Zarysowują się dwie możliwości rozwiązania tego problemu, tj. stypizowania zamachów terrorystycznych jako wyodrębnionych czynów przestępnych, traktując je jako samoistne byty prawne i jest to niezmiernie zabieg trudny legislacyjnie, na gruncie polskiego prawa karnego chyba niewykonalny lub ustalenie konstytutywnych cech przestępstwa o charakterze terrorystycznym, których wystapienie powoduje, że dany czyn jest kwalifikowany jako przestępstwo o charakterze terrorystycznym. Innymi słowy, chodzi o stworzenie pewnej matrycy normatywnej, której nałożeniem na dany czyn przestępny stwierdza się, czy mamy do czynienia z przestępstwem noszącym znamiona przestępstwa terrorystycznego. Jest to łatwiejszy sposób rozwiązania tego problemu. Takie właśnie rozwiązanie przyjął polski ustawodawca, wprowadzając ustawą z dnia 16 kwietnia 2004 r. ${ }^{1}$ do kodeksu karnego definicję przestępstwa o charakterze terrorystycznym $w$ art. $115 \S 20$. Jak będzie dalej o tym mowa, nie jest to w polskim prawie karnym rozwiązanie poprawne, którego wadliwość wynika nie z zastosowanej metody legislacyjnej, lecz z niewłaściwego określenia materii normatywnej w tym zakresie, inaczej mówiąc - niepoprawnego ustalenia matrycy. Powoduje to w praktyce poważne trudności w kwalifikacji prawnej danego czynu przestępnego jako czynu o charakterze terrorystycznym, zważywszy nadto, że terroryzm postrzega się we współczesnym świecie jako wyjątkowo groźne zjawisko, które zaburza pokój i normalność życia poszczególnych narodów. Jest to negatywny fenomen społeczny ponadnarodowy, którego przeciwdziałanie poważnie absorbuje poszczególne rządy, polityków, dziennikarzy, służby policyjne i wojsko- 
we, a także pracowników naukowych. Zjawisko to poraża najpotężniejsze mocarstwa na świecie (USA, Rosja). Nie sposób jest wypracować skutecznych systemów oraz środków przeciwdziałania temu zjawisku, nawet w sprawnie zorganizowanej współpracy międzynarodowej. Obecnie prawie wszystkie międzynarodowe służby o charakterze policyjnym i wojskowym mają na celu zwalczanie terroryzmu. Stosowane dotychczas metody i środki walki z terroryzmem okazują się mało skuteczne. Jak uczy doświadczenie, ograniczają się one w zasadzie do likwidacji skutków działania terrorystów, a nie sięgają do przyczyn. Oczywistym jest, że usuwanie objawów nie likwiduje ich źródeł. Taka walka, rzecz jasna, prowadzi donikąd. Można to prześledzić na przykładzie międzynarodowej operacji wojskowej w Afganistanie, gdzie do walki z terroryzmem zaangażowano poważne siły wojskowe (w tym i wojska polskiego) oraz sprzętu wojskowego o najnowocześniejszych rozwiązaniach. Walka ta prowadzona jest na prawach wojny. Jak dotychczas walka ta zaostrza się, giną żołnierze, a także ludność cywilna, a rozwiązania tego problemu nie ma, można powiedzieć nawet, że problem walki z terroryzmem w Afganistanie pogłębia się i jego końca nie widać. W Afganistanie świat ma do czynienia z klasycznym zjawiskiem terroryzmu. Poza Afganistanem występuje wiele ugrupowań na świecie nazywanych niekiedy terrorystycznymi, które określają się jako ugrupowania narodowowyzwoleńcze (np. ETA, IRA, partyzanci w Czeczeni i inne). Niektóre zorganizowane związki przestępcze zaliczane bywają także do ugrupowań o charakterze terrorystycznym. Taki stan rzeczy wymaga precyzyjnego określenia pojęcia terroryzmu, nad którym od wielu lat zastanawiają się politycy, specjaliści z prawa karnego i kryminologii, prawa międzynarodowego oraz inni zajmujący się problematyką terroryzmu i jak dotąd brak jest zadowalającego tutaj rezultatu. Ustalenie precyzyjnej definicji zjawiska terroryzmu jest bardzo ważne, gdyż jest to zjawisko groźne, napiętnowane we wszystkich cywilizowanych krajach i dobrze by było, aby wszędzie określono je w taki sam lub zbliżony sposób, a jego zakres i znaczenie ujmowano tak samo lub podobnie. W przeciwnym wypadku, a tak jest chyba obecnie, pewne zjawiska, które w jednym kraju są uznawane za terrorystyczne, w innych krajach uznawane są za zjawiska kryminalne. Wprawdzie zamachy terrorystyczne w konwencjach Narodów Zjednoczonych oraz w ramowej decyzji Rady UE z dnia 13.06.2002 r. są uznawane za przestępstwa kryminalne, jednakże motywacja ich popełniania wskazuje jednoznacznie na podłoże ideologiczne, o czym będzie dalej mowa. Można przyjąć, iż zjawisko terroryzmu jest także zjawiskiem kryminalnym, ale w takiej sytuacji trzeba szczególnie wyróżnić, dodając kryminalno-terrorystyczne ${ }^{2}$, wtedy będzie wiadomo, o jaką materię chodzi. 


\section{Pojęcie terroryzmu}

Jak wspomniałem, różnorodność i złożoność materii terroryzmu jako zjawiska społecznego powoduje, iż dotychczasowe próby zdefiniowania tego zjawiska zawodzą. Jak podaje B. Hołyst w najpoważniejszym dziele pt. „Terroryzm”, na świecie istnieje ponad 100 definicji terroryzmu. Rozbieżności różnych autorów są tutaj duże. Sam natomiast B. Hołyst wyróżnia trzy pojęcia terroryzmu, tj. terroryzm tradycjonalny działający na podłożu ideologicznym, socjalno-tendencyjnym i etniczno-nacjonalistycznym. Można przy jąć, iż jest to próba określenia klasycznego terroryzmu. B. Hołyst stwierdza tutaj, że według definicji FBI istota terroryzmu polega na sprzecznym z prawem użyciu przemocy, aby zmusić rządy do poparcia celów politycznych bądź społecznych. Terroryści chca, przez szkodliwe oddziaływanie na bezpośrednie ofiary, uderzyć w pośrednią bądź właściwą ofiarę (grupę docelowa), którą chcą zastraszyć, by podjęła działanie leżące w ich interesie. Akt terrorystyczny jest więc zdarzeniem, w którym z reguły uczestniczą co najmniej trzy strony: sprawcy, ofiary i grupa docelowa poddawana presji psychicznej. ${ }^{3}$ Drugim pojęciem terroryzmu wyróżnionym przez B. Hołysta jest terroryzm kryminologiczny, w którym odstępuje się od ideologicznych motywów działania sprawców. Z góry zakłada się, iż terrorysta dopuszcza się przestępstwa o charakterze kryminalnym. Wyłącza się zupełnie działanie terrorysty z motywów ideologicznych. Takie rozumienie terroryzmu jest przybliżone do pojęcia przestępstwa o charakterze terrorystycznym o jakim traktuje art. $115 \S 20 \mathrm{kk}$. Przepis ten stanowi, iż „Przestępstwem o charakterze terrorystycznym jest czyn zabroniony zagrożony karą pozbawienia wolności, której górna granica wynosi 5 lat, popełniony w celu:

1) poważnego zastraszenia wielu osób,

2) zmuszenia organu władzy publicznej Rzeczypospolitej Polskiej lub innego państwa albo organu organizacji międzynarodowej do podjęcia lub zaniechania określonych czynności,

3) wywołania poważnych zakłóceń w ustroju lub gospodarce Rzeczypospolitej polskiej, innego państwa lub organizacji międzynarodowej - a także groźba popełnienia takiego czynu."

Pojęcie to zostało wprowadzone do kodeksu karnego ustawą nowelizująca $\mathrm{z}$ dnia 16.04.2004 $\mathrm{r}^{4}$

Definicja ta wprowadziła wielkie nieporozumienie w prawie karnym w zakresie przestępstwa o charakterze terrorystycznym. Nieporozumienie to polega na tym,

Por. F. Ryszka, Terroryzm polityczy, wstep do problematyki fenomenu, (w:) Terroryzm polityczny, Warszawa 1981, s. 11. 
że autentyczna wykładnia określona w art. $115 \S 20 \mathrm{kk}$. przestępstwa terrorystycznego ustala, iż przestępstwem terrorystycznym może być każdy czyn zabroniony, zagrożony karą pozbawienia wolności, której górna granica wynosi najwyżej 5 lat, popełniony $w$ celu wymienionym $w$ tym przepisie $w$ trzech punktach, które to cele mogą wystąpić łącznie lub każdy z osobna. Występuje on bowiem w alternatywie zwykłej. Pierwszy z celów został określony, że czyn ten może mieć na celu poważne zastraszenie wielu osób. $Z$ tego wynika, że polska jest krajem o największym natężeniu zdarzeń terrorystycznych, gdyż prawie w każdym mieście, na różnych osiedlach działaja grupy młodzieżowe (gangi młodzieżowe), które dokonują uszkodzenia mienia, kradzieży z włamaniem do komórek, kradzieży, biorą udział w bójkach z użyciem niebezpiecznych narzędzi i innych czynów, m.in., w celu poważnego zastraszenia mieszkańców osiedla. Takie czyny, w rozumieniu art. $115 \S 20$ kk., należałoby kwalifikować jako zamachy terrorystyczne, a takie grupy młodzieżowe należałoby uznać za ugrupowania terrorystyczne. Władza publiczna w Polsce deklaruje, że Polska nie ma rodzimych grup terrorystycznych oraz dotychczas nie odnotowano zamachów o charakterze terrorystycznym. W statystyce kryminalnej też nie uwzględnia się zamachów o charakterze terrorystycznym. Z tego można wnioskować, iż organy ścigania nie przestrzegają przepisów kodeksu karnego odnośnie do czynów o charakterze terrorystycznym. W mojej ocenie postępują słusznie, gdyż tego typu zachowania młodzieżowe są zachowaniami noszącymi znamiona różnych przestępstw, których motywem nierzadko jest okazanie lekceważenia norm prawnych i zasad współżycia społecznego, lecz w żadnym razie nie można ich uznać za czyny o charakterze terrorystycznym, a ugrupowania te za terrorystyczne. Wykładnia autentyczna przestępstwa o charakterze terrorystycznym przewidziana $\mathrm{w}$ art. 115 par. 20 kk. powinna zostać poprawiona, należy do tej definicji dodać jednak element ideologicznego działania sprawców, niezależnie od tego, czy z mocy prawa będzie się ich traktować jako sprawców ciężkich przestępstw kryminalnych, a nie politycznych. Wówczas uniknie się nieporozumień w zakresie poprawności kwalifikacji prawnej czynu o charakterze terrorystycznym. Trzecim pojęciem terroryzmu, o którym wspomina B. Hołyst, jest terroryzm międzynarodowy. Rozumie się tutaj akty przemocy zmierzające do zniszczenia symbolicznego statusu, identyczności i bytu bądź istoty ofiary (społeczeństwa, instytucji, osób cywilnych). ${ }^{5}$

Wymaga zauważenia, że polski ustawodawca karny nie uwzględnił w zakresie regulacji przestępstw o charakterze terrorystycznym wymaganych zasad określoności i spójności norm prawa karnego, które przy tworzeniu przepisów prawa karnego, a także przy ich stosowaniu odgrywają bardzo ważna rolę. W sposób bezkrytyczny przyjął opis przestępstwa o charakterze terrorystycznym w decyzji ramowej Rady Unii Europejskiej z 13 czerwca 2002 r. w sprawie zwalczania terroryzmu,

Por. B. Hołyst, op. cit., t. 1, s. 54 
która to regulacja ma charakter przepisów z zakresu prawa administracyjnego, a nie prawa karnego. Decyzja ta, podobnie jak i konwencja Rady Europy z dnia 27 stycznia 1977 r. o zwalczaniu terroryzmu, nie zaliczają przestępstw terrorystycznych do przestępstw o charakterze politycznym. Podobne stanowisko znajduje się w konwencjach ONZ. Przepisy te z góry przesądzają, że przestępstwa terrorystycznego nie można popełnić z motywów ideologicznych. Wydaje się, iż należy jednak odróżnić tutaj dwie rzeczy, tj.: a) traktowanie sprawców przestępstw o charakterze terrorystycznym w przepisach prawa karnego i prawa wykonawczego tak jak groźnych sprawców przestępstw kryminalnych, nie przyznając im statusu więźniów politycznych (więźniów sumienia) i b) motywacje dokonywania przez tych sprawców przestępstw o charakterze terrorystycznym. Należy tutaj trzymać się rzeczywistego stanu rzeczy. Czym innym bowiem jest regulacja prawna, która nie przyznaje tym sprawcom statusu więźniów politycznych, a czym innym jest określenie motywacji ich działania. W tym zakresie oczywistym jest, że motywacja popełniania przestępstw o charakterze terrorystycznym jest ideologiczna.

Trzeba zwrócić uwagę na to, że ugrupowania terrorystyczne stanowią pewnego rodzaju tajne organizacje o charakterze politycznym, których strategią działania w osiąganiu założonych celów jest wywieranie presji na władze różnych krajów i organizacji międzynarodowych poprzez zastraszanie określonych grup społecznych w wyniku organizowania wybuchów i katastrof powodujących śmierć i kalectwo nieokreślonej grupy osób oraz poważnych zniszczeń w mieniu. W każdym razie zakładane cele działania przez ugrupowania terrorystyczne maja charakter ideologiczny. W aspektach kryminologicznych nie można utożsamiać tych ugrupowań z przestępczością mafijną lub inną przestępczością zorganizowaną o charakterze kryminalnym lub gospodarczym.

\section{Zaostrzenie odpowiedzialności karnej za czyny o charakterze terrorystycznym w kodeksie karnym}

Polska, wykonując zalecenia Rady Unii Europejskiej wynikające z decyzji ramowej z 13 czerwca 2002 r. w sprawie zwalczania terroryzmu, wprowadziła zaostrzenie odpowiedzialności karnej za przestępstwa o charakterze terrorystycznym oraz ustaliła wykładnię autentyczną przestępstwa o tym charakterze. Dokonała tego ustawą nowelizu jącą kodeks karny z dnia 16 kwietnia 2004 r. ${ }^{6}$ która weszła w życie w dniu 1.05.2004 r. ${ }^{7}$ Natomiast ustawą z dnia 25.06 .2009 r., ${ }^{8}$ która weszła w życie w dniu 22.10 .2009 r. w art. 165a kk. wprowadziła nowy typ przestępstwa dotyczący

Dz.U. Nr 93, poz. 889

Por. A. Marek, Prawo karne, 9 wyd., Warszawa 2009, s. 330

Dz.U. Nr 166, poz. 1317 
zakazu finansowania przestępstw o charakterze terrorystycznym. Jest to realizacja zaleceń międzynarodowej konwencji o zwalczaniu finansowania terroryzmu podjętej przez Zgromadzenie Ogólne Narodów Zjednoczonych w dniu 9.12.1999 r., ratyfikowanej przez Polskę w dniu 13.12.2004 r.

Zaostrzeniem odpowiedzialności wobec sprawców przestępstw popełnionych w warunkach recydywy szczególnej, wielokrotnej, o jakiej mowa w art. $64 \S 2$ kk., na mocy artykułu $65 \S 1$ objęto również przestępców zawodowych oraz działających w zorganizowanej grupie lub związku przestępczym, a także sprawców przestępstw o charakterze terrorystycznym. Zaostrzenie to polega na tym, że sprawcom takim sąd wymierza karę pozbawienia wolności powyżej dolnej granicy ustawowego zagrożenia, a może wymierzyć do górnej granicy ustawowego zagrożenia zwiększonego o połowę. Wobec takich sprawców przestępstw, zgodnie z art. $69 \S 3$ kk., nie stosuje się zawieszenia wykonania kary, chyba że zachodzi wyjątkowy wypadek, uzasadniony szczególnymi okolicznościami. W takiej sytuacji wykluczone jest nadzwyczajne złagodzenie kary w warunkach przewidzianych w art. $60 \S 3,4$ i 5 kk. Dotyczy to nadzwyczajnego złagodzenia kary w stosunku do sprawcy współdziałającego $\mathrm{z}$ innymi osobami w popełnieniu przestępstwa, jeżeli ujawni on wobec organu powołanego do ścigania przestępstw informacje dotyczące osób uczestniczących w popełnieniu przestępstwa oraz istotnych okoliczności jego popełnienia. $Z$ tego dobrodziejstwa nie mogą skorzystać, między innymi, sprawcy przestępstw o charakterze terrorystycznym. Zgodnie z $73 \S 2$ wobec określonego w art. $64 \S 2$ kk. sprawcy przestępstwa, dotyczy to także sprawcy przestępstwa o charakterze terrorystycznym; przy zawieszeniu wykonania kary pozbawienia wolności dozór kuratora jest obowiązkowy. Skazanego za przestępstwo o charakterze terrorystycznym można warunkowo zwolnić po odbyciu $3 / 4$ kary pozbawienia wolności, nie wcześniej jednak niż po roku odbycia tej kary (art. $78 \S 2 \mathrm{kk}$.). W takim wypadku okres próby tego skazanego wynosi najmniej 3 lata $(80 § 2 \mathrm{kk}$.).

Dalsze obostrzenia za popełnienie przestępstwa o charakterze terrorystycznym zawiera art. $258 \S 2$ i 4 kk., a także $65 \S 2$ kk. Przy tym $65 \S 2$ kk. stanowi, że do sprawców przestępstw przewidzianych w art. $258 \mathrm{kk}$. mają odpowiednie zastosowanie przepisy dotyczące odpowiedzialności karnej w warunkach recydywy szczególnej wielokrotnej (art. $64 \S 2$ kk.) z wyjątkiem zaostrzenia kary. Występuje tutaj zaostrzenie dotyczące warunkowego zawieszenia wykonania kary (art. $69 \S 3$ kk.), dozoru obligatoryjnego (art. $73 \S 2 \mathrm{kk}$.), warunkowego przedterminowego zwolnienia z odbycia reszty kary (art. $78 \S 2$ kk.), okresu próby (art. $80 § 2$ kk.)

Art. 258 kk. określa odpowiedzialność karną za działanie w zorganizowanej grupie przestępczej lub $w$ związku przestępczym. W $\S 1$ określa typ podstawowy tego przestępstwa. W $\S 2$ przewiduje typ kwalifikowany z zaostrzonym ustawowym wymiarem kary od 6 miesięcy do 8 lat. Typ ten kwalifikuje dwie przesłanki, tj. i bez- 
pieczeństwo, jeśli a) grupa lub związek przestępczy mają charakter zbrojny, albo b) mają na celu popełnienie przestępstwa o charakterze terrorystycznym.

W 33 przewidziana jest zaostrzona odpowiedzialność karna wobec osób, które zakładają lub kierują grupą lub związkiem przestępczym, w tym mające charakter zbrojny, od roku do 10 lat. Najostrzejszą odpowiedzialność powoduje $\S 4$, który stanowi, że kto grupę albo związek mające na celu popełnienie przestępstwa o charakterze terrorystycznym zakłada lub takim związkiem lub grupa kieruje, podlega karze pozbawienia wolności na czas nie krótszy od lat 3 . A więc jest to zbrodnia w rozumieniu prawa karnego.

Według A. Marka związkiem przestępczym jest ugrupowanie co najmniej 3 osób, o względnie trwałej strukturze organizacyjnej, posiadające nie tylko wspólny cel, lecz także konkretny program, formy współdziałania i podział zadań, wyłonione kierownictwo oraz ustalone zasady członkostwa. Jeśli chodzi o zorganizowane grupy, to w przeciwieństwie do związku przestępczego nie muszą one mieć długotrwałego programu i ustalonych zasad przynależności. Praktyka dowodzi, że ugrupowania terrorystyczne są dobrze zorganizowane, mają ustalone struktury i kierownictwo, występuje tam żelazna dyscyplina, jest ustalone członkostwo, a więc w przedstawionym rozumowaniu są związkami przestępczymi. ${ }^{9}$

Przestępstwo finansowania terroryzmu przewidziane w art. 165a kk. jest przestępstwem nowym w polskim prawie karnym, zagrożonym karą pozbawienia wolności od 2 do 12 lat. Jest to więc przestępstwo o dużej szkodliwości społecznej. Dotyczy ono zakazu finansowania działalności terrorystycznej. Jak zauważa Zgromadzenie Ogólne Narodów Zjednoczonych w preambule, finansowanie różnych form terroryzmu służy jego rozwojowi i godzi w międzynarodowy pokój i bezpieczeństwo. Finansowanie tej działalności może odbywać się w sposób bezpośredni lub pośredni, m.in., przez organizacje o charakterze charytatywnym, społecznym lub kulturalnym, a także organizacje prowadzące nielegalną działalność, jak: nielegalny handel bronia, handel narkotykami oraz wymuszenia do finansowania działań terrorystycznych. Brak środków finansowych do prowadzenia tej działalności uniemożliwia wykonanie poważniejszych zamachów terrorystycznych, zwłaszcza na arenie międzynarodowej. Rodzajowym przedmiotem ochrony przestępstwa finansowania terroryzmu jest bezpieczeństwo powszechne. Finansując tę działalność, która godzi w bezpieczeństwo powszechne, tj. w życie i zdrowie nieokreślonej grupy przypadkowych osób oraz mienie w znacznych rozmiarach, tym samym zagraża się temu dobru chronionemu prawem. Indywidualnym zaś przedmiotem ochrony tego przestępstwa jest legalność obrotu finansowego. Ochrania się tutaj obrót finansowy przed jego wykorzystaniem na działalność terrorystyczną. Wykorzystanie występujących w danym obrocie środków finansowych na cele terrorystyczne jest bowiem

Por. A. Marek, op. cit., s. 652. 
niezgodne z prawem. Sprawcą może być w tym przestępstwie każda osoba zdatna do odpowiedzialności karnej w rozumieniu prawa karnego. Musi spełniać przesłanki podmiotowe do odpowiedzialności karnej, tj. mieć ukończone 17 lat życia oraz być poczytalną lub poczytalną ograniczoną w stopniu znacznym. Od strony podmiotowej omawianego przestępstwa można się dopuścić tylko w winie umyślnej w zamiarze bezpośrednim. Działanie sprawcy jest tutaj ukierunkowane na sfinansowanie przestępstwa o charakterze terrorystycznym. Od strony przedmiotowej sprawca gromadzi, przekazuje lub oferuje środki płatnicze, instrumenty finansowe, papiery wartościowe, wartości dewizowe, prawa majątkowe lub mienie ruchome lub nieruchomości w celu sfinansowania działalności terrorystycznej. Finansowanie może tutaj polegać na: a) gromadzeniu środków majątkowych, które może przybrać różne formy. Przepis nie stanowi o jakie gromadzenie chodzi; b) przekazywanie środków majątkowych w różny sposób. Może to być przekazywanie bezpośrednie lub pośrednie. Co do nieruchomości, może to być np. zapis lub darowizna. Środki pieniężne można przekazać na rachunek bankowy lub bezpośrednio; c) oferowanie środków majątkowych może polegać na różnych formach proponowania ich wykorzystania, np. na rzekome cele charytatywne lub kulturalne. Rodzaje środków majątkowych zostały przykładowo wymienione w dyspozycji art. 165a kk., jak: środki płatnicze, którymi może być waluta danego kraju (np. euro, USD, PLN), instrumenty finansowe, papiery wartościowe, wartości dewizowe, które są określone w prawie dewizowym, prawa majątkowe lub inne mienie ruchome lub nieruchomości, jak: działki, budynki, mieszkania.

Możliwe popełnienie przestępstw przez zamachy terrorystyczne

Do typowych form zamachów terrorystycznych zalicza się:

1) piractwo powietrzne lub morskie,

2) zamachy bombowe na budynki, pociągi, dworce lub inne urządzenia użyteczności publicznej, w których znajduje się większa ilość ludzi,

3) zamachy wobec nieokreślonej grupy ludności cywilnej,

4) porywanie osób w celu wymuszenia określonego zachowania się władz publicznych. ${ }^{10}$

Mając na względzie typizację przestępstw w części szczególnej kodeksu karnego, najbardziej zagrożonymi popełnieniem przez zamachy terrorystyczne są następujące przestępstwa:

1) art. 118 kk. - eksterminacja ludności,

2) art. 119 kk. - dyskryminacja, 
3) art. 120 kk. - stosowanie środków masowej zagłady,

4) art. 128 kk. - zamach na konstytucyjny organ RP,

5) art. 134 kk. - zamach na życie Prezydenta RP,

6) art. 140 kk. - zamach na jednostki sił zbrojnych RP,

7) art. 148 kk. - zabójstwo,

8) art. 165a kk. - finansowanie przestępstwa o charakterze terrorystycznym,

9) art. 168 i 170 kk. - przestępstwo przeciwko bezpieczeństwu powszechne$\mathrm{mu}$,

10) art. 173 - 175 kk. - przestępstwo przeciwko bezpieczeństwu w komunikacji,

11) art. 252 kk. - wzięcie zakładnika,

12) art. $258 \S 2$ i $\S 4$ kk. - związek o charakterze terrorystycznym.

Są to przestępstwa, które z natury rzeczy mogą najczęściej występować przy zamachach terrorystycznych. Sprawcy tych zamachów mogą ponosić odpowiedzialność za popełnienie tych właśnie typów przestępstw. Można przyjąć, iż polskie prawo karne jest dostosowane do zwalczania groźnych zjawisk współczesnych czasów, noszących znamiona przestępstw, w tym o charakterze terrorystycznym.

\section{Wnioski końcowe}

1. Zjawisko terroryzmu jest bardzo złożone i różnorodne. Ujęcie jego materii w poprawną i jednoznaczną definicję jest jak dotąd niewykonalne. W literaturze przedmiotu występuje ponad 100 definicji i żadna $\mathrm{z}$ nich nie jest zadowalająca.

2. Zjawisko terroryzmu jest o tyle niebezpieczne, że współczesne najgroźniejsze organizacje działające na obszarach wielu krajów, działające w ukryciu, np. AlKaida, wykonują zamachy na terytorium krajów, które zaliczają do swoich przeciwników. Prowadzą również działania bojowe, jak np. w Afganistanie. W niektórych sytuacjach trudno jest ustalić, czy ma się do czynienia z walką narodowowyzwoleńczą, czy też z terroryzmem, np. Czeczenia, ETA, IRA i inni.

3. W takiej sytuacji ustalenie wykładni przestępstwa terrorystycznego do celów poprawnej kwalifikacji prawnej czynu jest bardzo trudne. Dlatego też wykładnia autentyczna przestępstwa terrorystycznego dokonana w art. $115 \S 20 \mathrm{kk}$. przez polskiego ustawodawcę karnego jest niedoskonała i wymaga poprawienia na drodze legislacyjnej. Wydaje się, iż wprowadzenie do tej definicji całostki w postaci moty- 
wacji ideologicznej działania sprawcy wyeliminowałoby kwalifikowanie do terroryzmu czynów młodzieżowych gangów osiedlowych. W przeciwnym wypadku należy wobec tych grup stosować zaostrzoną odpowiedzialność karną, jak w wypadku terroryzmu.

4. Akty prawa międzynarodowego, jak i prawa europejskiego jednoznacznie kwalifikują zjawiska terroryzmu do groźnych przestępstw o charakterze kryminalnym. Tak uczynił również polski kodeks karny. Przepisy tych aktów prawnych nie stwarzają możliwości do zaliczania przestępstw o charakterze terrorystycznym oraz ich sprawców do kategorii przestępstw i przestępców politycznych. Niemiej jednak z kryminologicznego punktu widzenia oczywistym się wydaje, iż ugrupowania terrorystyczne i dokonywane przez nie zamachy posiadają podłoże ideologiczne. Można sprawcom tych czynów z mocy przepisów prawa nie przyznać statusu więźniów sumienia, ale nie można zakłamywać rzeczywistości, a rzeczywistość jest taka, że zamachy terrorystyczne są dokonywane w oparciu o motywacje ideologiczna.

5. Ogólnie rzecz biorąc, polskie prawo karne zostało dostosowane do wymogów ONZ i UE w zakresie zwalczania terroryzmu. Posiada zaostrzoną odpowiedzialność karną za te czyny. Odpowiedzialność terrorystów została zaostrzona do poziomu odpowiedzialności za recydywę szczególną wielokrotną. Zostało także wprowadzone przestępstwo o wysokiej szkodliwości społecznej, wyrażonej w ustawowym wymiarze kary, zakazujące finansowania przestępstw o charakterze terrorystycznym. 


\section{WPKYW PRAWA EUROPEJSKIEGO NA UNORMOWANIA PRZESTĘPSTWA O CHARAKTERZE TERRORYSTYCZNYM W POLSCE}

Ustalenie wykładni przestępstwa terrorystycznego do celów poprawnej kwalifikacji prawnej czynu jest bardzo trudne. Jego ujęcie w normy prawa karnego napotyka także na poważne trudności.

Akty prawa międzynarodowego, europejskiego i polski kodeks karny jednoznacznie kwalifikują zjawiska terroryzmu do groźnych przestępstw o charakterze kryminalnym. Przepisy tych aktów prawnych nie stwarzają możliwości do zaliczania przestępstw o charakterze terrorystycznym oraz ich sprawców do kategorii przestępstw i przestępców politycznych. Niemiej jednak z kryminologicznego punktu widzenia oczywistym się wydaje, iż ugrupowania terrorystyczne i dokonywane przez nie zamachy posiadają podłoże ideologiczne. Można sprawcom tych czynów z mocy przepisów prawa nie przyznać statusu więźniów sumienia, ale nie można zakłamywać rzeczywistości, a rzeczywistość jest taka, że zamachy terrorystyczne są dokonywane w oparciu o motywacje ideologiczna. 
THE IMPACT OF THE EUROPEAN LAW ON POLISH REGULATION CONCERNING CRIMINAL OFFENCE OF TERRORISM

The way to determine and interpret the criminal offence of terrorism for the purpose of correct legal qualification of the action is very difficult. Its inclusion in the standards and frames of penal law also sits uneasily.

Acts of the public international law, the European law and also provisions of the Polish Penal Code, explicitly qualify the phenomenon of terrorism to serious criminal offences (crimes). The provisions of these acts have not made it possible to categorize terrorism as a political offence and its perpetrators as political offenders. However, from the point of view of the criminologist, it seems obvious that groups of terrorists and their attacks have their genesis in ideology. It is not possible to provide, under the provisions of law, the offenders with the status of prisoners of conscience but one should not distort reality. And the reality is, that terrorist attacks are made on the basis of an ideological motivation.

Key words: terrorism, criminal law, qualification, prisoners of conscience, ideological motivation 